\title{
Measuring the level of community desire to use GWJ application in office activities
}

\author{
S.P. Marsofiyati ${ }^{a}$, Nuryetty Zain ${ }^{a}$, Henry Eryanto ${ }^{a}$ and Osly Usman ${ }^{a}$
}

${ }^{a}$ Universitas Negeri Jakarta, Indonesia

CHRONICLE ABSTRACT

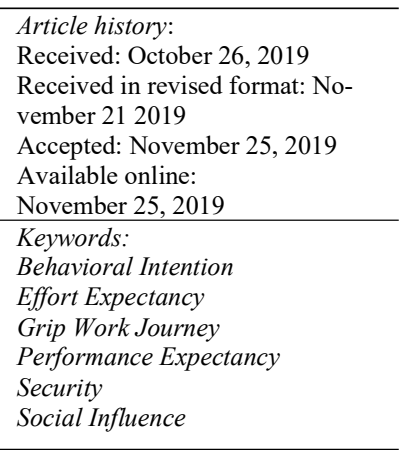

\begin{abstract}
This study aims to find out the level of community desire within the university to use the Grip Work Journey (GWJ) application in office activities as an e-office application. The method used is quantitative research with data analysis techniques using Partial Least Square (PLS), and the data collection process is performed through a questionnaire. Respondents in this study were 200 people. The results of the study state that performance expectancy, effort expectancy, social influence, and security maintained positive influences on Behavioral Intention Grip Work Journey as a community office application in Jakarta State University.
\end{abstract}

\section{Introduction}

Universities now entering a period of implementation of the technology race. Although the technology is here to survive and accessing it has increased, this does not automatically lead to the effective use of technology in educational practice (Park et al., 2008). In support of that office work has become increasingly complicated and complex and it is necessary to use ICTbased applications. Therefore, there are new design of an android-based application secretarial work named Grip Work Journey $(\mathrm{GWJ})$, which is based on Information and Communication Technology (ICT) and is expected to improve the effectiveness and efficiency of secretarial and administrative work. The new product design is an application that can be used on Android based smartphones. Applications Product Grip Work Journey (GWJ) is a design application that containss 6 (six) main menu that has been developed recently. The main sixth menu consists of a mail, notes, reminders, schedule, news and contact and it is associated with the effective use of educational technology. However, measuring success is highly dependent on the context, the variables studied, and most importantly, the original purpose of implementation (DeLone \& McLean, 2003), The admission process technology and the use of technology by the intended users is the key in implementing educational technology, which can be researched through intention (behavior) to use or actual use of technology (DeLone \& McLean, 2003; Venkatesh et al., 2003). Unified Theory of Acceptance and Use of Technology (UTAUT) has been a widely recognized instrument for measuring user acceptance, operationalized as behavioral intentions or actual use by ourselves (Venkatesh et al., 2003), UTAUT predicts user acceptance and therefore appeal to all potential implementers of new technologies (Pynoo et al., 2011) as administrator of the institution. UTAUT emerges through the review and consolidation of eight models that compete and are conceptually similar to those used to predict or explain the behavior (Venkatesh et al., 2003). Joint and efficient models feature four core variables that predict behavioral intention and actual use: Performance Expectancy (PE), Effort Expectancy (EE), Social Influence (SI) and Facilitating conditions (FC). PE associated is the belief * Corresponding author.

E-mail address: marsofiyati@unj.ac.id (S.P. Marsofiyati) 
that the use of technology will help users do their jobs better, EE catches the level of convenience associated users with a technology, the SI shows how users perceive that others are important to them (co-workers, supervisors) and believe that they should be using technology and, most recently, FC is a scale that includes the level of skills of trainees, support, infrastructure, and background knowledge that is available to use the system optimally (Pynoo et al., 2011). In this case, the university can benefit from knowing the potential determinants that affect the acceptance and use of the application, which in turn can lead to the development of specialized training geared towards the effective use of innovative educational technology in practice. Acceptance of educational technology is already learned by the students, but it has not been widely studied from the standpoint of the administrator of the university staff as users (Garone et al., 2019; Kocaleva et al., 2014).

\section{Theoretical framework}

\subsection{GWJ (Grip Work Journey)}

The development of increasingly sophisticated technology in the implementation of activities within the company. Good use of technology will have a good effect in the course of the company. Utilization of technology in carrying out office work can help every company and even lead in carrying out work to be more effective and efficient. Seeing current conditions, everyone will not escape from cellphone use. In other words, everyone today will definitely have a cellphone. These conditions can be utilized in the management of companies through the use of offices. The products we produce are products based on Information and Communication Technology (ICT). Products with increasing technological sophistication are expected to help improve the effectiveness and efficiency of each worker. A Grip Work Journey application has six content which is useful in helping the office work. Content: (1) Mail, the Mail content contained process and store the letters typed letter and can send a letter that has been made; (2) Note, in this content users are making of the new record and the record history. On the menu there is a which can be saved; (3) Reminder, this is used as a reminder of the important activities; (4) Schedule, the content contains the schedule scheduling daily activities, weekly and monthly. (5) News, on this item contains all the latest news, we can make our own (internal) and outside the company news (external) both domestically and abroad. News is externally connected through a link kompas.com. (6) Contact, in this content there is a list of contact relations of companies that deal directly with users or leaders.

\subsection{Performance Expectancy}

Performance expectancy is a variable that can be referred to as the ability to obtain significant benefits after using a system (Ozyilmaz et al., 2018), Performance expectancy is UTAUT construct intended to measure the level of a person's belief that by using a system that can help one in achieving his job performance (Venkatesh et al., 2003). Expectation of performance is defined as an individual's understanding of the benefits of using innovation on the advantages of using technology innovation that produces better (Zhou et al., 2010). According to Brown et al. (2016) performance expectations is the extent to which the use of mobile payments benefits customers and leads to profit performance. According to Ozyilmaz et al. (2018) performance expectancy level is a person's believes that the use of the system will help to gain and improve profitability in the work. Meanwhile, according to Rahi et al. (2018) performance expectancy is defined as the extent to which the user's perception of superior performance with the use of internet banking on his duties is, and believe it will help to achieve the benefits in fulfilling user's banking operations. Performance expectancy is a representation of the five constructs including perceived usefulness (technology acceptance model), external motivation (motivational model), work correlation (model of personal computer utilization), relative advantage (definition of innovation) and expectancy to the achievement (social cognitive theory) (Ozyilmaz et al., 2018). Based on the above research performance expectancy is defined the level of confidence that the use of electronic banking would improve efficiency in the transaction by using a system that can help one in achieving his job performance.

\subsection{Effort Expectancy}

According to Venkatesh et al. (2003) effort expectancy is expected effort as the associated level of convenience when using any system. Thus the effort expectancy refers to the effort required to use the system. Efforts expectancy is defined as the level of convenience associated with the use of a payment (Venkatesh et al., 2012). According to Liebenberg et al. (2018) effort expectancy is a level of convenience associated with the use of a particular system. Meanwhile, according to Ahmad (2014) effort expectancy is the level of ease of use of the system. Effort expectancy is the level of effort of each individual in the use of a support system to do the work (Venkatesh, et al., 2003). According to Ozyilmaz et al. (2018) effort expectancy refers to how easily a person is thinking in using a system. Effort expectancy is a representation of the three constructs including a consciousness of easy to use (Technology Acceptance Model), systematic complexity (Model of Personal Computer Utilization) and operating simplicity (Innovation Diffusion Theory).

\subsection{Social Influence}

Social influence refers to the extent to which individuals feel it is important for people including family and friends to use technology (Martin \& Herrero, 2012). Venkatesh et al. (2012) also illustrates the extent to which social influences an individual cares about the opinions and perceptions of others. 
Social influence is the level at which a person considers important for others to convince him to use the new system (Venkatesh et al., 2003). Social influence refers to the feelings of a person to feel that people who are important to him think that he had to use an application (Arifin et al., 2015). According to Singh and Srivastava (2018), social influence can be defined as an act, or certain habits (particular behavior) others that can affect a person's perception. Besides, the concept of social influence is developed from the concept of subjective norm, social factors, and image (Rahi et al., 2018). Social influence can be different relative to the user's environment, if the workplace is almost certainly a colleague, while at home the possibility of a family. Social influence by Venkatesh et al. (2003) is a representation of the three constructs including subjective norm (theory of reasoned action, technology acceptance models and theory of planned behavior), public image (innovation diffusion theory) and social factors (the model of personal computer utilization). Social influence depends on the influence of the environment that includes volunteerism, and other contexts between individuals and the effect on the organization.

\subsection{Security}

Currently the organization becomes more dependent on information technology, an emphasis on information security becomes more significant (Yayla, 2011), As a result, the effects of time pressure and stress has been debated in the field of information and computer security (Yildiz, 2018). Whitman (2004) considers 'action or failure to human error' as one of the most severe threats to information security. The literature indicates that some of the fundamental reasons behind the error is due to the time pressure and stress. West (2008) summarizes the principles of decision-making in computer security. Consistent with the theory of cognitive decision making that has been discussed before, he suggests people have the time and mental resources are limited when making decisions regarding online safety. As a result, West believes that users are often motivated to continue the major task as soon as possible and, therefore, less likely to make a decision pro-security (West, 2008), For example, in cases where the user is prompted to install a software update, scan files for viruses before opening, and so, users tend to adhere to when in the middle of another task (West, 2008). Furthermore, Yayla (2011) considers the effects of stress-related time pressures on individuals in information security. He proposed that the errors and omissions arguably the two threats to the 'threat of accidental' time pressure. Yayla (2011) suggests that reducing levels of stress and fatigue related to work by adjusting the pressure of time and workload will reduce the threat of accidental insiders to information security. Security has the technical and behavioral aspects. Common sense suggests that the more technical security is present, the more the perceived behavior of security is. Technical security refers to the existence of a way that will prevent unauthorized access to a computer or computer network, while referring to the security of the subjective individual perception that using the application will be free of risk (Skinner et al., 2009).

\subsection{Behavior Intention}

Behavioral Intention is one of the key concepts in understanding the UTAUT technology acceptance model. Interest or intention of using information technology (behavioral intention) can be defined as a person's level of desire or intention to use technology constantly assuming the factors that influence it are met (Venkatesh, et al. 2012). In general, one would be interested in using an information technology posed to him if he believes that by using information technology to improve its performance, its use is relatively easy, and he gains influence from the surrounding environment (social influence) for the use of information technology. The level of acceptance of information technology by the user can be predicted from the attitudes and perceptions of the users of these technologies, such as the desire to add support tools or seek support such as support, motivation to continue to use, as well as the desire to affect other users. Theories and models regarding acceptance of technology has also been developed since the 1980 s by a variety of variables (Momani \& Jamous, 2017), In general, the variables in a variety of models that have been used are explained that intrinsic motivation, experience, and social conditions play a major role in the acceptance of the technology, so it can be generalized that the behavior (behavior) the user plays an important role in the decision making in the use of technology. Based on the review of some of the above studies, behavioral intention in this study can be defined as factors that affect the user to continue using the service GWJ application. So it can be formulated four indicators of behavioral intention as follows:

1. Interest in the use of applications

2. Increased efficiency increase

3. Increased effectiveness

4. Improved performance of service

\subsection{Hypothesis}

Based on what explained in the previous section, the proposed model of this survey is demonstrated in Fig. 1 and the the following hypotheses are proposed.

$\mathrm{H}_{1}$ : Performance Expectancy has a positive influence on Behavioral Intention.

$\mathrm{H}_{2}$ : Effort Expectancy has a positive influence on Behavioral Intention.

$\mathrm{H}_{3}$ : Social Influence has a positive influence on Behavioral Intention.

$\mathrm{H}_{4}$ : Security has a positive influence on Behavioral Intention.

$\mathrm{H}_{5}$ : Performance expectancy, effort expectancy, social influence, and security a positive influence on Behavioral Intention. 


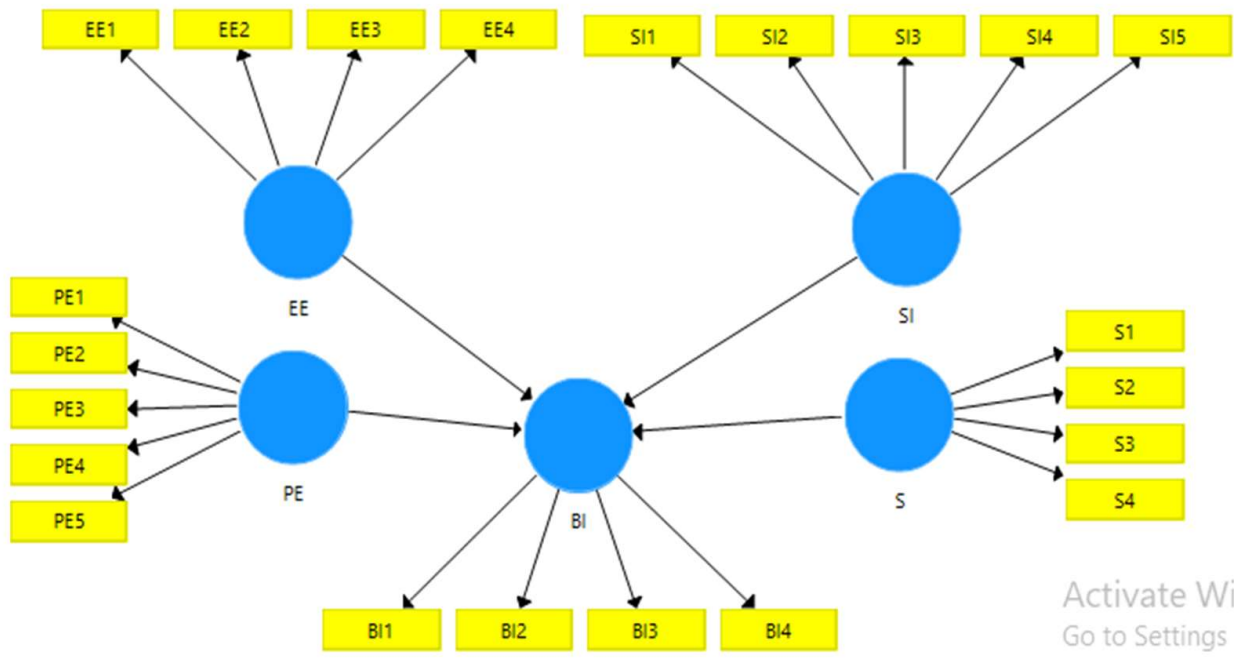

Source: Data processed by Author

Fig. 1. Research Model by SmartPLS

\section{Research methodology}

Based on the problems that researchers formulated, then the purpose of this study is to get proper knowledge and credible implementation of GWJ application. The method used in this study is a survey method, to get the correct data and following the facts directly from the source used comparative approach. Besides, this study uses a quantitative approach in which each data is implemented in the form of numbers which are then analyzed to generate statistical value.

Table 1

Operational Definition of Variables

\begin{tabular}{|c|c|c|c|c|}
\hline variables & variable definition & Dimension & Indicator & Expert \\
\hline $\begin{array}{l}\text { Performance } \\
\text { Expectancy } \\
\text { (PE) }\end{array}$ & $\begin{array}{c}\text { The level of confidence that } \\
\text { the use of electronic banking } \\
\text { would improve efficiency in } \\
\text { the transaction. }\end{array}$ & $\begin{array}{l}\text { Expectations of } \\
\text { electronic banking } \\
\text { technology }\end{array}$ & $\begin{array}{l}\text { Perceptions of users } \\
\text { Extrinsic Motivation } \\
\text { suitability jobs } \\
\text { Relative Advantages } \\
\text { expectations Results }\end{array}$ & $\begin{array}{l}\text { (Venkatesh, V., } \\
\text { Thong, J.Y.L., \& } \\
\text { Xu, 2012) }\end{array}$ \\
\hline $\begin{array}{c}\text { Effort Expectancy } \\
\text { (EE) }\end{array}$ & $\begin{array}{l}\text { The level of ease of use of the } \\
\text { electronic banking system. }\end{array}$ & Ease Using e-banking & $\begin{array}{l}\text { Ease of users to understand the e- } \\
\text { banking } \\
\text { Ease of users to interaction with e- } \\
\text { banking } \\
\text { Ease of users to do e-banking }\end{array}$ & (Ahmad, 2014) \\
\hline Social Influence (SI) & $\begin{array}{l}\text { An act, or certain habits of } \\
\text { others that can affect a person's } \\
\text { perception }\end{array}$ & Social factors & $\begin{array}{l}\text { Influence others } \\
\text { Effect of bank management } \\
\text { The influence of the workplace } \\
\text { The influence of psychographic } \\
\text { (prestige) }\end{array}$ & $\begin{array}{c}\text { (S. Singh \& } \\
\text { Srivastava, 2018) }\end{array}$ \\
\hline Security (S) & $\begin{array}{c}\text { Security level electronic } \\
\text { banking system }\end{array}$ & $\begin{array}{l}\text { Safe use of electronic } \\
\text { banking system }\end{array}$ & $\begin{array}{l}\text { Privacy } \\
\text { Authentification } \\
\text { Integrity } \\
\text { Non-repudiation }\end{array}$ & (Rahi et al., 2018) \\
\hline $\begin{array}{c}\text { Behavioral Intention } \\
\text { (BI) }\end{array}$ & $\begin{array}{c}\text { Human beings can be said to } \\
\text { be free and not free }\end{array}$ & $\begin{array}{l}\text { Interest in the use of } \\
\text { electronic banking } \\
\text { system }\end{array}$ & $\begin{array}{l}\text { The use of e-banking interest } \\
\text { Increased efficiency } \\
\text { Increasing the effectiveness } \\
\text { Improved performance of service }\end{array}$ & Liebenberg 2018 \\
\hline
\end{tabular}

Source: Data processed by Author

\section{Results and discussion}

An indicator is said to be valid if it has a loading factor above 0.5 against the intended constructs. Output SmartPLS for loading factors provide the following results: 


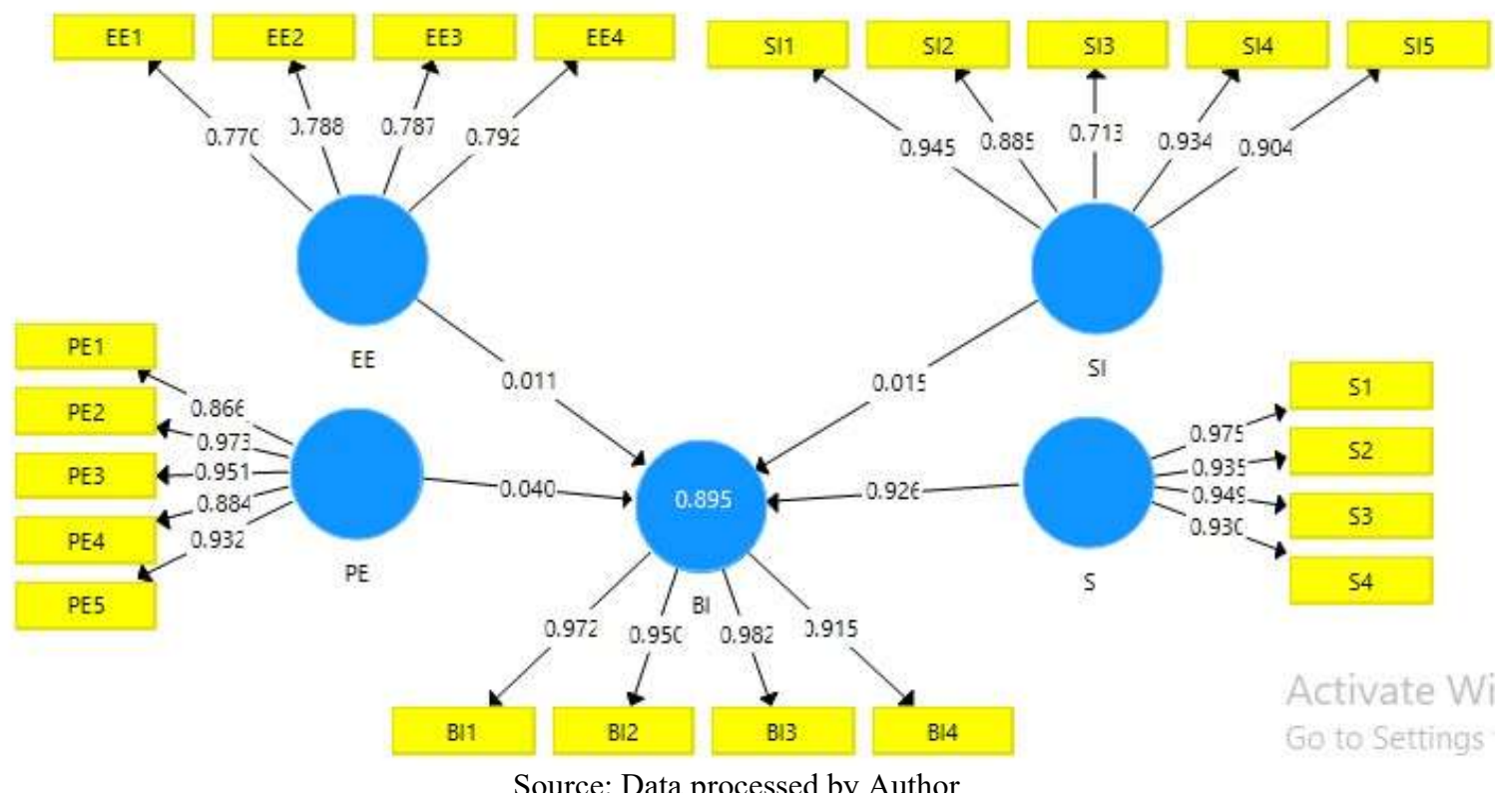

Source: Data processed by Author

Fig. 2. SmartPLS output result

All indicators have a loading factor value above 0.5 , it can be said that the indicators used in this study are valid or have met the convergent validity. Further, reflective indicators also need to be tested by cross loading discriminant validity as follows:

Table 2

Loading factor

\begin{tabular}{|c|c|c|c|c|c|}
\hline & Behavioral Intention & Effort Expectancy & Performance Expectancy & Security & Social Influence \\
\hline BI1 & 0,972 & & & & \\
\hline BI2 & 0,950 & & & & \\
\hline BI3 & 0,982 & & & & \\
\hline BI4 & 0,915 & & & & \\
\hline EE1 & & 0,770 & & & \\
\hline EE2 & & 0,788 & & & \\
\hline EE3 & & 0,787 & & & \\
\hline EE4 & & 0,792 & & & \\
\hline PE1 & & & 0,866 & & \\
\hline PE2 & & & 0,973 & & \\
\hline PE3 & & & 0,951 & & \\
\hline PE4 & & & 0,884 & & \\
\hline PE5 & & & 0,932 & & \\
\hline S1 & & & & 0,975 & \\
\hline S2 & & & & 0,935 & \\
\hline S3 & & & & 0,949 & \\
\hline S4 & & & & 0,930 & \\
\hline SI1 & & & & & 0,945 \\
\hline SI2 & & & & & 0,885 \\
\hline SI3 & & & & & 0,713 \\
\hline SI4 & & & & & 0,934 \\
\hline SI5 & & & & & 0,904 \\
\hline
\end{tabular}

Source: Data processed by Author

An indicator is said to be valid if it contains the highest loading factor on the targeted construct loading factor compared to other constructs. The criteria in the cross loading is that each indicator is higher with its construct compared to other constructs. The output of cross loading is shown in Table 2 which shows that the loading factor of each indicator for the construct is higher loading factor to other constructs. Another method to see discriminant validity is to look at the value of the square root of the average variance extracted (AVE) to the recommended values above 0.5 . Table 3 summarizes the results of AVE values 
in the study. Table 3 shows that the value AVE all the variables above 0.5. Lowest AVE value amounted to 0.615 at Effort Expectancy construct. Reliability testing is done by looking at the value of the block of composite reliability indicator that measures the construct. Results of composite reliabilities are reliable if the values are above 0.3 but will produce a satisfactory value if it is more than 0.7 . Furthermore, reliability testing may be approved by Cronbach's Alpha wherein the resulting output has a value above 0.3 and it is said to be reliable. In this study, all constructs have a value of Cronbach's alpha and composite reliability above 0.7 and that value means that constructs used reliable.

Table 3

Reliability and Validity

\begin{tabular}{lcccc}
\hline & Cronbach's Alpha & rho_A & Composite Reliability & Average Variance Extracted (AVE) \\
\hline Behavioral Intention & 0,968 & 0,973 & 0,977 & 0,865 \\
Effort Expectancy & 0,796 & 0,804 & 0,912 & 0,615 \\
Performance Expectancy & 0,956 & 0,979 & 0,966 & 0,851 \\
Security & 0,962 & 0,965 & 0,972 & 0,898 \\
Social Influence & 0,925 & 0,943 & 0,945 & 0,775 \\
\hline
\end{tabular}

Source: Data processed by Author

\subsection{Hypothesis Test}

Table 4

Path Coefficient (Mean, STDEV, T-Value, P-Value)

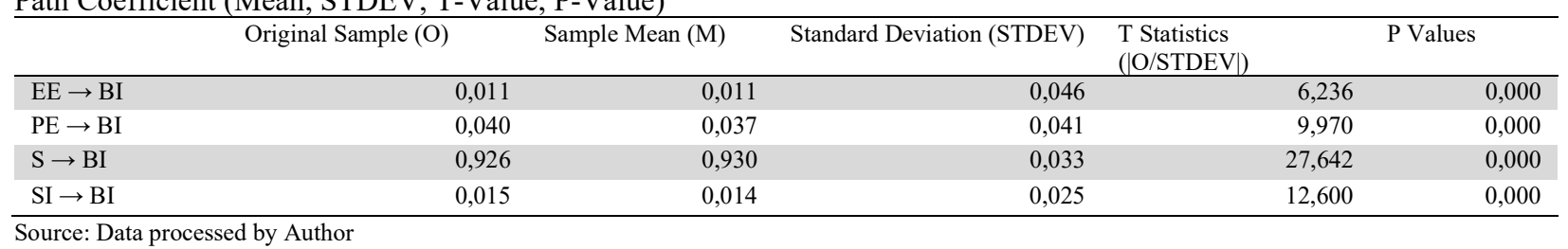

The influence between PE against BI in this study is said to be significant with a t-statistic of 9.970 (>1.96). The original value estimate is a positive sample is 0.040 which indicates that the direction of the relationship between PE with $\mathrm{BI}$ is positive. Therefore, the first hypothesis (H1) in this study that states that Performance Expectancy (PE) has a positive and significant effect on Behavioral Intention (BI). The value of the t-statistic variable towards EE with BI of 6.236 (>1.96). The original value estimate is a positive value of 0,011 which indicates that the direction of the relationship between EE with $\mathrm{BI}$ is positive. Therefore, the first hypothesis (H2) in this study that states that Effort Expectancy (EE) has a positive and significant effect on Behavioral Intention (BI).

The effect of SI on BI in this study is said to be significant with a t-statistic of $12.600(>1.96, \mathrm{p}$-value $=0.015)$, which indicates that the direction of the relationship between SI with BI is positive. Therefore, the first hypothesis (H3) in this study states that Social Influence (SI) positive and significant effect on Behavioral Intention (BI). The effect of S on BI in this study is said to be significant with a t-statistic of $27.642(>1,96)$, which indicates that the relationship between $\mathrm{S}$ and $\mathrm{BI}$ is positive. Therefore, the hypothesis (H4) in this study that states that Security (S) positive and significant effect on Behavioral Intention (BI) is confirmed. Based on above presentation, this study explained that the Performance Expectancy, Effort Expectancy, Social Influence and Security influence on Behavioral Intention especially by using the GWJ application. In this research, it was found that each indicator has a positive and significant influence on other indicators.

\section{Conclusion}

1. Performance Expectancy positively influences the Behavioral Intention with a significance level of 9.970 and direction of the relationship between Performance Expectancy with Behavioral Intention is positive.

2. Effort Expectancy positively influences the Behavioral Intention with a significance level of 6.236 and direction of the relationship between Effort Expectancy with Behavioral Intention is positive.

3. Social Influence positively influences the Behavioral Intention with a significance level of 6.236 and direction of the relationship between Social Influence with Behavioral Intention is positive.

4. Security positively influences the Behavioral Intention with a significance level of 27.642 and direction of the relationship between Security with Behavioral Intention is positive.

5. Performance expectancy, effort expectancy, social influence, and security have positive effects on Behavioral Intention.

Therefore, we can conclude that the level of community desire within the university to use the Grip Work Journey (GWJ) application in office activities as an e-office application can be improved. 


\section{Suggestion}

We suggest the IT society to develop new products and services by using sophisticated technology. The use of good technology will have an impact on the company's journey. Utilization of technology in carrying out office work can help every company and even lead in carrying out work to be more effective and efficient. Seeing current conditions, everyone will not be separated from the use of mobile phones. In other words, everyone today will definitely own a cellphone. This condition can be utilized in company management through the use of offices.

\section{Acknowledgement}

The authors would like to thank the anonymous referees for constructive comments on earlier version of this paper.

\section{References}

Ahmad, M. I. (2014). Unified theory of acceptance and use of technology (UTAUT): A decade of validation and development. Proceedings of the 4th International Conference on ICT in Our Lives (ISSN 2314-8942).

Arifin, M. Y., Suswandi, P. E., \& Adenan, M. (2015). Pengaruh Pengeluaran Pemerintah Sektor Kesehatan, Pengeluaran Pemerintah Sektor Pendidikan dan Pertumbuhan Ekonomi terhadap Indeks Pembangunan Manusia Jawa Timur 20062013. Artikel Ilmiah Mahasiswa.

Brown, S.A., Dennis, A.R., \& Venkatesh, V. (2016). Predicting collaboration technology use: integrating technology adoption and collaboration research. Journal of Management Information Systems,. 27(2), 9-53.

Delone, W. H., \& McLean, E. R. (2003). The DeLone and McLean model of information systems success: A ten-year update. Journal of Management Information Systems, 19(4), 9-30.

Garone, A., Pynoo, B., Tondeur, J., Cocquyt, C., Vanslambrouck, S., Bruggeman, B., \& Struyven, K. (2019). Clustering university teaching staff through UTAUT: Implications for the acceptance of a new learning management system. British Journal of Educational Technology, 50(5), 2466-2483. https://doi.org/10.1111/bjet.12867

Kocaleva, M., Stojanovic, I., \& Zdravev, Z. (2014). Research on UTAUT application in higher education institutions. In: ITRO 2014, 27 June 2014. Zrenjanin, Serbia.

Liebenberg, J., Benade, T., \& Ellis, S. (2018). Acceptance of ICT: Applicability of the Unified Theory of Acceptance and Use of Technology (UTAUT) to South African Students. The African Journal of Information Systems, $10(3), 1$.

Martin, H.S., \& Herrero, A. (2012). Influence of the user's psychological factors on the online purchase intention in rural tourism: integrating innovativeness to the UTAUT framework. Tourism Management, 33(2),. 341-350.

Momani, A. M., \& Jamous, M. (2017). The Evolution of Technology Acceptance Theories.

Ozyilmaz, A., Erdogan, B., \& Karaeminogullari, A. (2018). Trust in organization as a moderator of the relationship between self-efficacy and workplace outcomes: A social cognitive theory-based examination. Journal of Occupational and Organizational Psychology, 91(1), 181-204.

Park, N., Lee, K. M., \& Cheong, P. H. (2008). University instructors' acceptance of electronic courseware: An ap-plication of the technology acceptance model. Journal of Computer-Mediated Communication, 13(1), 163-186.

Pynoo, B., Devolder, P., Tondeur, J., Van Braak, J., Duyck, W., \& Duyck, P. (2011). University students' ac-ceptance of a web-based course management system. In T. Teo (Ed.), Technology acceptance in education. Leiden, The Netherlands: Sense Publishers.

Rahi, S., Ghani, M., Alnaser, F., \& Ngah, A. (2018). Investigating the role of unified theory of acceptance and use of technology (UTAUT) in internet banking adoption context. Management Science Letters, 8(3), 173-186.

Skinner, E. A., Kindermann, T. A., Connell, J. P., \& Wellborn, J. G. (2009). Engagement as an organizational construct in the dynamics of motivational development (Handbook o; Malwah, ed.). NJ: Erlbaum.

Venkatesh, V., Morris, M. G., Davis, G. B., \& Davis, F. D. (2003). User acceptance of information technology: Toward a unified view. MIS Quarterly, . 425-478.

Venkatesh, V., Thong, J.Y.L., \& Xu, X. (2012). Consumer acceptance and use of information technology: extending the unified theory of acceptance and use of technology. MIS Quarterly,. 36(1), 157-178.

West, R. (2008). The psychology of security. Communications of the ACM,. 51(4), 34-40.

Whitman, M. E. (2004). In defense of the realm: understanding the threats to information security. International Journal of Information Management, 24(1), 43-57.

Yayla, A. A. (2011). Controlling insider threats with information security policies. In ECIS. 242.

Yildiz, E. (2018). A Case Study on Relationships Between Psychological Capital, Personality and Organizational Commitment. International Journal of Business Administration, 9(2), 99. https://doi.org/10.5430/ijba.v9n2p99

Zhou, T., Lu, Y., \& Wang, B. (2010). Integrating TTF and UTAUT to explain mobile banking user adoption. Computers in Human Behavior,. 26(4), 760-767. 
(C) 2020 by the authors; licensee Growing Science, Canada. This is an open access article distributed under the terms and conditions of the Creative Commons Attribution (CC-BY) license (http://creativecommons.org/licenses/by/4.0/). 